\title{
Titanium dioxide-assisted photocatalytic induction of prophages to lytic cycle
}

\author{
Ekaterina V. Skorb, ${ }^{* a, d}$ Daria V. Andreeva, ${ }^{b}$ Andrey P. Raiski, ${ }^{c}$ Natalya A. Belyasova,${ }^{c}$ Helmuth Möhwald ${ }^{a}$ and \\ Dmitry V. Sviridov ${ }^{d}$
}

Received 22nd June 2011, Accepted 11th October 2011

DOI: 10.1039/c1pp05195d

The investigations on the kinetics of photocatalytic inactivation of bacteriophages, lactic bacteria and lysogenic lactic bacteria have shown that the rate of bacterial inactivation is $c a .10$ times less than the inactivation of bacteriophages. Titania-assisted photorelease of bacteriophages from lysogenic bacteria proves that photogenerated reactive oxygen species affect the deoxyribonucleic acid (DNA) of bacteria before their deactivation. On this basis a novel photocatalytic method of a prophage induction to the lytic cycle and detection of lysogenic bacteria is proposed.

\section{Introduction}

In the last decades, $\mathrm{TiO}_{2}$ photocatalysis has attracted great attention as a promising method for water and air cleaning. ${ }^{1-4}$ Highly-active radical species produced at $\mathrm{TiO}_{2}$ surfaces under UV irradiation can participate in a series of oxidation reactions. In particular, hydroxyl radicals are generated by photoholes from the $\mathrm{TiO}_{2}$ valence band and superoxide ions are formed due to interaction of photoelectrons from the conduction band with molecular oxygen. Thus, the destruction of organic contaminants and their mineralization is expected. ${ }^{5-8}$ As strong oxidants, the reactive oxygen species generated by $\mathrm{TiO}_{2}$ photocatalytic reactions cause a variety of damage in microorganisms, leading to their rapid inactivation. Since the pioneering work of Matsunaga et al. ${ }^{9}$ reported the microbiocidal effects of platinised $\mathrm{TiO}_{2}$, the interest towards $\mathrm{TiO}_{2}$-assisted photocatalytic inactivation has risen intensely.

These disinfection studies established the basic photokilling mechanisms and identified the effective disinfection factors. ${ }^{9-14}$ It is also obvious that accurate kinetic data of photoinactivation is a prerequisite for the design of an effective photocatalytic disinfection system. ${ }^{14}$ Inaccurate estimation of a system's performance may lead to inadequate use and wasted financial investment. Therefore, a robust mechanistic model is needed to determine the most efficient combination of contact time, catalyst quantity and light exposure. ${ }^{14}$ Understanding the fundamental reactions which occur during the photocatalytic process will be important in improving and modelling the process for different

${ }^{a}$ Max Planck Institute of Colloids and Interfaces, Wissenschaftspark Golm, Am Mühlenberg 1, 14476, Golm, Germany.E-mail: skorb@mpikg.mpg.de; Fax: +49331567 9202; Tel: +493315679233

${ }^{b}$ Physical Chemistry II, University of Bayreuth Universitätstr, 30, 95440, Bayreuth, Germany

'Biotechnology and Ecology Department, Belarusian State Technological University, Sverdlova Str 13a, 220050, Minsk, Belarus

${ }^{d}$ Department of Chemistry, Belarusian State University, Leningradskaya Str 14, 220030, Minsk, Belarus microorganisms (bacteria, viruses, fungi, algae, protozoa). ${ }^{15}$ In contrast to bacteria ${ }^{9-15}$ the mechanism of inactivation of simple biological structures (viruses, phages) still remain unclear. We focus here on bacteriophage (Lactococcus phage, Siphoviridae 936) and Gram-positive bacteria (Lactococcus lactis (L. lactis)). The bacteriophage was chosen as a microorganism as it has a simple organization when compared to bacteria, and phages are more resistant to UV-inactivation. Recently it was shown, that titaniaassisted inactivation of Gram-negative bacteria occurs faster than that of Gram-positive bacteria due to their different cell wall morphology. ${ }^{13-15}$ Therefore, the UV exposure ensuring the inactivation of Gram-positive bacteria should be enough to provide complete inactivation of Gram-negative bacteria. In the presence of photocatalysts capable of the efficient production of superoxide ions (e.g., $\mathrm{TiO}_{2}$ modified by bimetallic $\mathrm{Ag}-\mathrm{Ni}$ particles) the rate of inactivation of Gram-positive bacteria increases dramatically. ${ }^{13}$ Here, we use the unmodified photocatalyst to ensure a relatively low rate of inactivation of model microorganisms, allowing us to trace the kinetics of this process.

Along with inactivation kinetic studies, fundamental research is needed in order to fill the gaps in the existing knowledge of the application of photocatalysis, not just for disinfection but also for detection. As a model for detection based on unmodified $\mathrm{TiO}_{2}$ photocatalysis, we suggest the photocatalytic scenario of titaniaaffected prophage (DNA of Lactococcus phage, Siphoviridae P335, $\mathrm{x} 411-\mathrm{f}$ and $\mathrm{x} 415-\mathrm{f}$ ) induction to lytic cycle accompanied with their release from lysogenic Gram-positive bacteria (L. lactis).

\section{Experimental}

The strains of Lactococcus lactis bacteria were obtained from a collection of the Department of Biotechnology and Bioecology of the Belarusian State Technological University (Table 1). All cultures were allocated from a surface of green parts of plants and identified by phenotype with the use of molecular-genetic tests. Bacteria were cultivated by standard methods at $30{ }^{\circ} \mathrm{C}$ in liquid or on the condensed peptide, M17 media containing $0.5 \mathrm{wt} \%$ 
Table 1 Biological objects used for photocatalytic inactivation studies

\begin{tabular}{lll}
\hline Subjects & Species & Strains (feature) \\
\hline Lactic acid bacteria (L. lactis) & Lactococcus lactis, ssp. lactis & 411 \\
& & 415 \\
& & 509 \\
& Lactococcus lactis, ssp. cremoris & $404 / 2$ \\
Lactococcus phages (family Siphoviridae) & Lactococcus lactis, ssp. diacetilactis & 502 \\
& 936 & 503 \\
& P335 & BIM BV-30 (virulent phage) \\
& & x411-f (temperate phage) \\
& & x415-f (temperate phage) \\
\hline
\end{tabular}

of glucose. ${ }^{16-18}$ The nanodispersed $\mathrm{TiO}_{2}$ Hombikat UV 100 from Sachtleben Chemie was used as the photocatalyst.

A two-layer method was used for revealing negative colonies of phages. ${ }^{19}$ The bottom layer consists of M17 agar (1.0 $\left.\mathrm{wt}^{\%} \%\right)$ media containing glucose $(0.5 \mathrm{wt} \%), \mathrm{CaCl}_{2}\left(5 \mathrm{mM} \mathrm{l}^{-1}\right)$ and glycin $(0.75 \mathrm{wt} \%)$. The top layer differed from the bottom layer only by the agar concentration $(0.4 \mathrm{wt} \%)$. For evaluating the sensitivity of the phages to photocatalytic action of $\mathrm{TiO}_{2}, 1 \mathrm{ml}$ prophage lysates with concentration $c a .1 .2 \times 10^{9}$ plaque-forming units $(\mathrm{PFU}) \mathrm{ml}^{-1}$ and $5 \mathrm{mg}$ of $\mathrm{TiO}_{2}$ powder or $\mathrm{SiO}_{2}$ powder (used in the control experiments) were placed into a Petri dish with a diameter of $25 \mathrm{~mm}$. For photocatalytic experiments, a $365 \mathrm{~nm}$ line of a $120 \mathrm{~W}$ high-pressure $\mathrm{Hg}$ lamp was used; the light intensity was $15 \mathrm{~mW}$ $\mathrm{cm}^{-2}$. The exposed suspensions were diluted by $10^{3}$ and cast over agar layers with model culture L. lactis 411 onto M17 medium. The incubation period was $24 \mathrm{~h}$. After incubation the PFU ml $\mathrm{m}^{-1}$ was determined, taking into account the dilution factor.

To induce the lytic cycle in prophages, lysogenic bacteria cultures in a stationary growth phase were irradiated with UV light. Lysogenic bacteria ( $c$ a $10^{9}$ colony-forming units $(\mathrm{CFU}) \mathrm{ml}^{-1}$ ) were diluted 100 -fold with $0.15 \mathrm{M} \mathrm{NaCl}$ solution. $3 \mathrm{ml}$ of bacteria suspension and $20 \mathrm{mg}$ of powder were placed into a sterile Petri dish with diameter of $60 \mathrm{~mm}$ and stirred continuously during irradiation. Immediately after exposure, suspensions were cultivated using the two-layer method (the M17 media) described above.

PCR analysis was performed according to Ref. 20.

For the preparation of samples for TEM investigations, the phagolysate $\left(\sim 10^{9}\right.$ PFU ml $\left.{ }^{-1}\right)$ was centrifuged at $6000 \mathrm{rpm}$ for $10 \mathrm{~min}\left(+4{ }^{\circ} \mathrm{C}\right)$ and the supernatant was centrifuged at $20000 \mathrm{rpm}$ for $10 \mathrm{~min}\left(+4{ }^{\circ} \mathrm{C}\right)$. The precipitate was then diluted by adding $1 \mathrm{ml} 0.1 \mathrm{M}$ ammonium acetate solution, centrifuged at $20000 \mathrm{rpm}$ for $10 \mathrm{~min}\left(+4{ }^{\circ} \mathrm{C}\right)$ and diluted by adding $15 \mathrm{ml}$ of $0.1 \mathrm{M}$ ammonium acetate solution. Then $10 \mu \mathrm{l}$ of suspension, together with $10 \mu 1$ of $2 \%$ tungsten phosphoric acid solution were placed onto a copper grid. The liquid was removed after $1 \mathrm{~min}$ by touching the edge of the grid with blotting paper. The samples were dried at room temperature.

\section{Results and discussion}

\section{Bacteriophage inactivation}

Phage BIM BV-30 with intermediate sensitivity to chemical inactivating factors, as well as Gram-positive bacteria L. lactis have been chosen as model systems for kinetic study of $\mathrm{TiO}_{2}$ assisted photoinactivation (Table 1).

We performed the experiments of bacteriophage titration on the tested bacteria after UV irradiation $(\lambda=365 \mathrm{~nm})$ in presence of titanium dioxide and silicon dioxide. Inactivation of bacteriophages under UV light irradiation was drastically enhanced in the presence of $\mathrm{TiO}_{2}$ photocatalysts: 20 min irradiation decreased the phages reproduction activity by a factor of 33 . The pathophysiological activity of the $\mathrm{TiO}_{2}$ photocatalyst against bacteriophages can be attributed to high oxidation power inherent in reactive oxygen species produced at the surface of titania particles under supra-bandgap illumination. TEM investigations show that the oxidation by reactive oxygen species causes photostimulated denaturation of the capsid and tail (Fig. 1). Finally, it affects specific adsorption of bacteriophage and/or damages molecules of nucleic acids

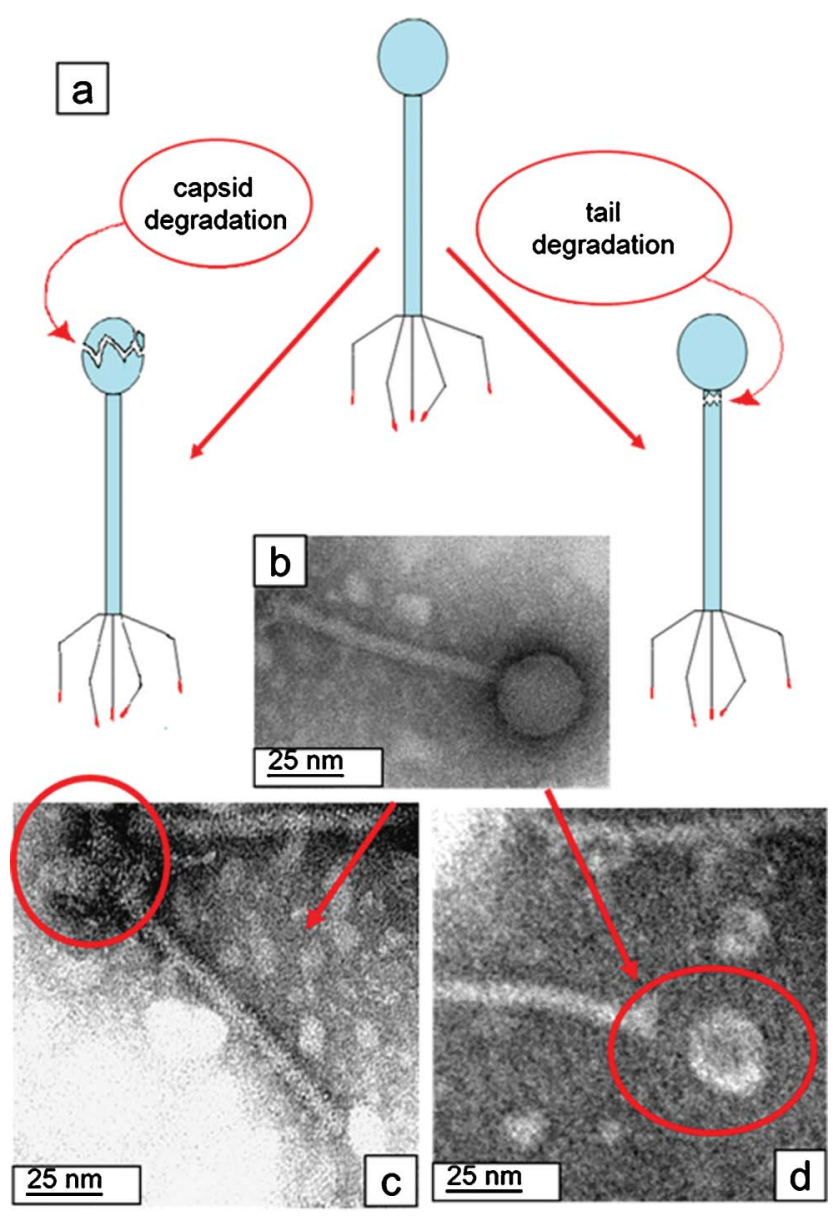

Fig. 1 (a) Schematic representation of phage deactivation. (b) Transmission electron microscopic (TEM) images of initial phages. (c, d) TEM images of phages after UV irradiation in the presence of titania. 
Table 2 Bacteria survival and induction of prophages to the lytic cycle under UV irradiation in the presence of a photocatalyst

\begin{tabular}{|c|c|c|c|c|c|}
\hline \multirow[b]{2}{*}{ Strains } & \multirow[b]{2}{*}{$C_{o},{ }^{a} \mathrm{CFU} \mathrm{m} l^{-1}$} & \multirow[b]{2}{*}{$C_{o},{ }^{b} \mathrm{CFU} \mathrm{ml} l^{-1}$} & \multirow[b]{2}{*}{$S, c \%$} & \multicolumn{2}{|c|}{ Concentration of phages (PFU ml ${ }^{-1}$ ) after UV irradiation ${ }^{d}$ with } \\
\hline & & & & $\mathrm{TiO}_{2}$ & $\mathrm{SiO}_{2}$ \\
\hline L. lactis 411 & $1.2 \times 10^{9}$ & $4.3 \times 10^{8}$ & 35.8 & $2.3 \times 10^{2}$ & 0 \\
\hline L. lactis 415 & $1.4 \times 10^{9}$ & $6.7 \times 10^{8}$ & 47.9 & $1.1 \times 10^{2}$ & 0 \\
\hline
\end{tabular}

The photogenerated reactive oxygen species cause a DNA chain breakage, followed by the fragmentation of the DNA molecules. We observed the significant reduction of luminescence intensity of phage DNA strips in agarose gel after separation by electrophoresis. Furthermore, we detected an absence of changes in DNA electrophoretic mobility and intensity of luminescence of the strips formed by assays of DNA exposed to the UV irradiation in solution without reagents or with photocatalyticallyinert $\mathrm{SiO}_{2}$ (Fig. 2). Similar results were obtained for the DNA assay kept for $60 \mathrm{~min}$ in darkness in the presence of $\mathrm{TiO}_{2}$. An assay of DNA exposed in the presence of $\mathrm{TiO}_{2}(60 \mathrm{~min}$, $\lambda=365 \mathrm{~nm}$ ) showed appreciable reduction of luminescence intensity in gel-electrophoresis and, therefore, a decrease of initial molecule concentration. Obviously, during UV-irradiation the reactive oxygen species generated on a surface of $\mathrm{TiO}_{2}$ cause the destruction of DNA accompanied by formation of large number of fragments.

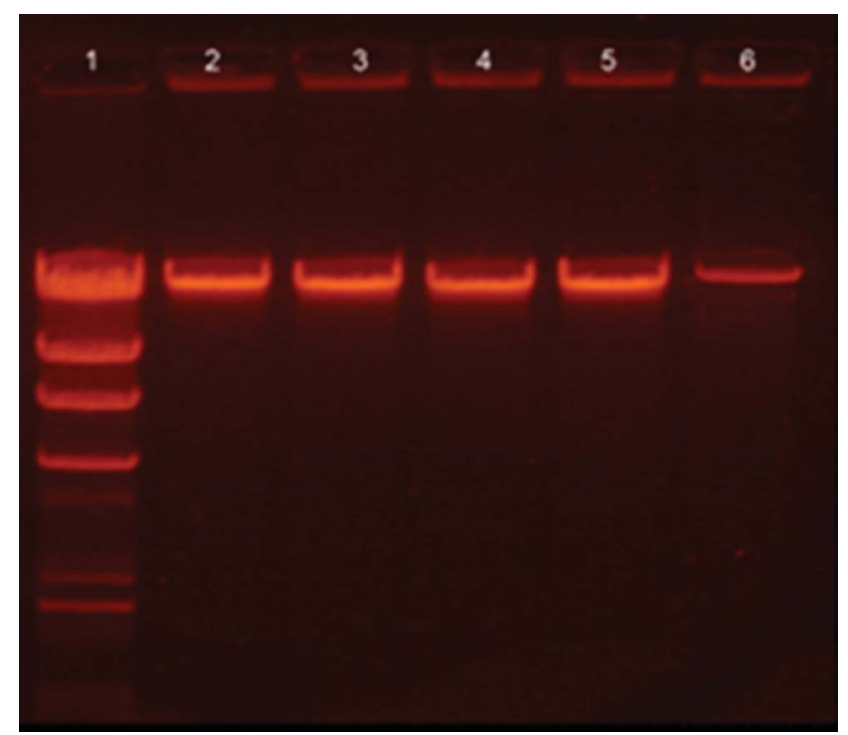

Fig. 2 Bacteriophage BIM BV-30 DNA gel-electrophoresis. (1) DNA-ladder $\lambda$ /HindIII, (2) native phage DNA, (3) DNA after UV irradiation in the absence of photocatalyst, (4) DNA after UV irradiation in the presence of $\mathrm{SiO}_{2}$, (5) blank experiment (DNA was kept in darkness in the presence of $\mathrm{TiO}_{2}$ ), (6) DNA after UV irradiation in the presence of $\mathrm{TiO}_{2}$.

\section{Photocatalytic induction of prophages to lytic cycle}

Lysogenic (i.e., containing DNA of prophage) and non-lysogenic L. lactis strains have been chosen as model systems for demonstrating the possibility of photocatalytic detection of lysogeny, employing $\mathrm{TiO}_{2}$. Prominent features of lysogenic bacteria populations is the inheritance of prophages. However, the lysogenic state is extremely unstable due to the antagonism of repressor proteins of the lytic cycle, and antirepressors.

The results of the photocatalytic experiments, collated in Table 2, provide evidence for the ability of the titania photocatalyst to induce the lytic cycle in the population of lysogenic cells. Even short-term $(2 \mathrm{~min})$ irradiation of lysogenic strains in the presence of titania photocatalyst leads to induction of bacteriophages to lytic cycle. On the contrary, UV irradiation in the presence of photocatalytically-inactive $\mathrm{SiO}_{2}$ does not lead to negative colonies of free phages at after 2 min, nor after $2 \mathrm{~h}$ of irradiation.

The induction of bacteriophages to the lytic cycle due to photocatalytic treatment of bacteria L. lactis 411 was monitored by TEM. Fig. 3 demonstrates that bacteriophage are leaving L. lactis 411 bacterium under the titania-assisted photocatalytic stimulus.
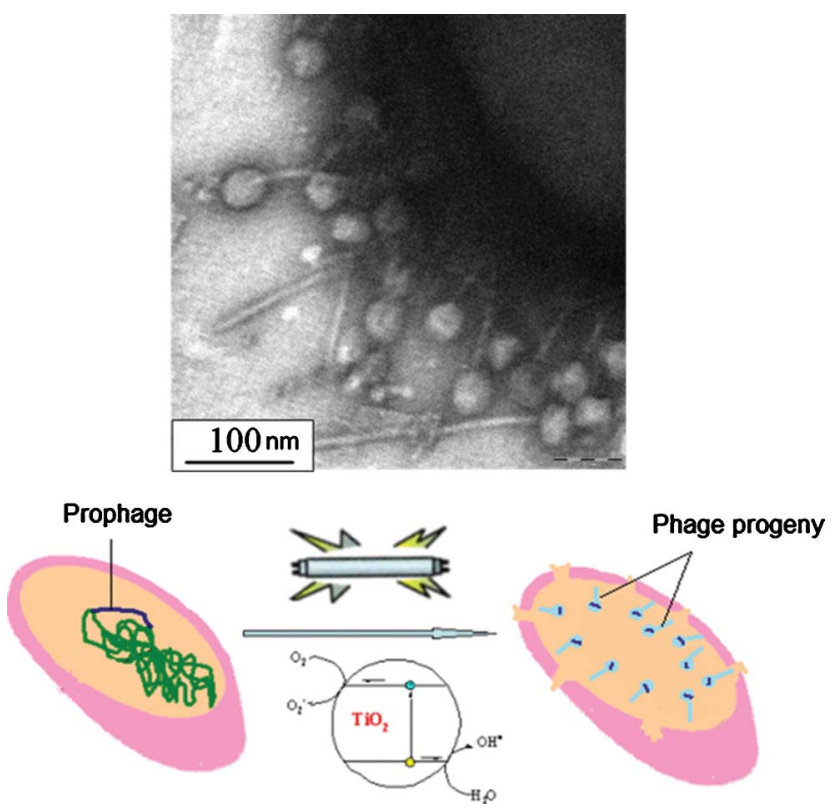

Fig. 3 TEM image showing mature phages leaving bacterium L. lactis 411 exposed to UV light in the presence of $\mathrm{TiO}_{2}$; below the schematic representation of photo induced release of bacteriophage from lactic bacteria is given.

The virulent phages (Table 1) may originate from damage of temperate phages. Thus, any factors that damage the structure of DNA are potentially able to provide transformation of the temperate phages into the virulent form, and induce the lytic cycle in a population of lysogenic cells. 
Table 3 The effect of UV irradiation in the presence of catalyst on the concentration of bacteria L. lactis and their prophages

\begin{tabular}{|c|c|c|c|c|}
\hline \multirow[b]{2}{*}{ Bacteria } & \multirow[b]{2}{*}{ 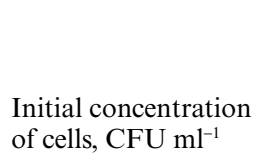 } & \multirow[b]{2}{*}{$\begin{array}{l}\text { Concentration of cells }\left(\mathrm{CFU} \mathrm{ml}{ }^{-1}\right) \\
\text { after } \mathrm{UV} \text { irradiation }\end{array}$} & \multicolumn{2}{|c|}{$\begin{array}{l}\text { Concentration of phages in the irradiated } \\
\text { suspensions }\left(\mathrm{PFU} \mathrm{ml}{ }^{-1}\right) \text { in the presence of }\end{array}$} \\
\hline & & & $\mathrm{TiO}_{2}$ & $\mathrm{SiO}_{2}$ \\
\hline L. lactis 411 & $1.2 \times 10^{7}$ & $4.3 \times 10^{6}$ & $2.3 \times 10^{2}$ & 0 \\
\hline L. lactis 415 & $1.4 \times 10^{7}$ & $6.7 \times 10^{6}$ & $1.1 \times 10^{2}$ & 0 \\
\hline L. lactis $404 / 2$ & $2.0 \times 10^{7}$ & $5.9 \times 10^{6}$ & $0.8 \times 10^{1}$ & 0 \\
\hline
\end{tabular}

For the detection of lysogenic bacteria, two approaches are traditionally used (i) PCR, (ii) photochemical method ${ }^{21}$ consisting of a long-term strong UV irradiation (LTSUVI) followed by registering of suspension turbidity (Fig. 4). The proposed third approach, (iii) titania-assisted pathway of photocatalytic DNA biodetection is much more efficient, saving both time and energy.

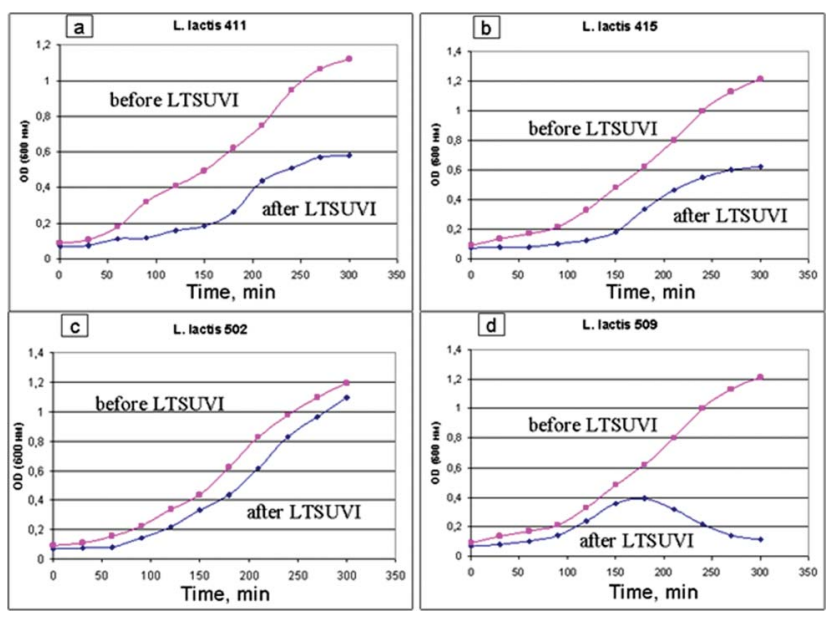

Fig. 4 Time dependencies of optical density for bacterial cultures before and after long-term strong UV irradiation (LTSUVI): (a) L.lactis 411, (b) L.lactis 415, (c) L. lactis 502, (d) L. lactis 509.

The visual changes in the optical density of suspensions with time after LTSUVI $(\lambda=240 \mathrm{~nm})$ were determined for the 20 cultures of L. lactis isolated from the surface of the green parts of plants. However, we did not register the expected stop of pattern growth of the culture. Fig. 4 shows the time dependencies obtained for the chosen strains. Thus there were doubts as to whether, after LTSUVI, the bacteria are lysogenic or not. The cells of L. lactis ssp. lactis 411, are lysogenic as shown by PCR analysis. The second strain, L. lactis subsp. cremoris 502, a non-lysogenic bacteria, was susceptible to several virulent phages. The cells of both strains showed slightly discernible growth retardation after UV irradiation. The free phages were not identified in the suspensions of UV-irradiated bacteria by cross test: phage-negative colonies were not registered. The LTSUVI method thus can't provide 100\% accuracy in bacteria lysogeny detection. It is necessary to repeat such tests several times, or resort to using the PCR method, which is not everywhere available. We can solve the problem using the photocatalyst; simultaneously we can drastically decrease the time of irradiation and detect bacteria lysogeny in all cases.

We performed the PCR analysis of $L$. lactis DNA using oligonucleotide primers $\mathrm{P} 335 \mathrm{~A}$ and $\mathrm{P} 335 \mathrm{~B}$ that are specific to the unique sequences of the genomes of temperate phage species P335.
We observed prophage-like structures in cells of three strains. The presence of amplification products of the required size (196 bp) formed in the process of PCR analysis of chromosomal DNA of bacteria L. lactis subsp. lactis 415 , L. lactis subsp. lactis 411 and L. lactis subsp. lactis 404/2 indicate the presence of the DNA of the temperate phage P335 species, or prophage-like elements in the genomes of these bacteria. These strains were used in further experiments on photocatalytic induction of prophages in the presence of titanium dioxide photocatalyst to determine photocatalytic method efficiency.

Table 3 presents data on the survival of bacteria and the effect on induction of prophages to the lytic cycle after $2 \mathrm{~min} \mathrm{UV}$ irradiation $(\lambda=365 \mathrm{~nm})$ of cell suspensions in the presence of the semiconductor photocatalyst $\left(\mathrm{TiO}_{2}\right)$ and the inert substance $\left(\mathrm{SiO}_{2}\right)$. The production of DNA fragments was observed for two of the tested strains to ensure, by contrast, that no DNA fragments were present in the suspensions, observed after UV irradiation in contact with the dispersed $\mathrm{SiO}_{2}$.

Furthermore, PCR analysis demonstrates the presence of DNA fragments of the temperate phage species P335 in the bacteria $L$. lactis ssp. lactis 404/2 in the tested bacteria after UV irradiation in the presence of $\mathrm{TiO}_{2}$, whereas the free phages were not detected. The latter fact can be attributed to the typical to Lactococcus and their phages phenomenon of inheritance of chromosomal DNA prophage-like elements.

Primers 5' GAAGCTAGGCGAATCAGTAAACTTGCTAG 3' and 5' CGGCTATCTCGTCAATTGT TCCGGTTGC 3' were used to detect temperate phage DNA of group P335 in bacteria L. lactis 411 and L. lactis 415 (Fig. 5). Bacteria L. lactis 411 and L. lactis 415 with $\mathrm{TiO}_{2}$ phages were propagated on non-lysogenic strain L. lactis subsp. cremoris 502. The lysates (x411-f and x415-f) were analyzed by PCR with the above mentioned primers. Both lysates have provided occurrence characteristic for phages of group P335 (Fig. 5a). Fig. 5b shows the formation of negative colonies
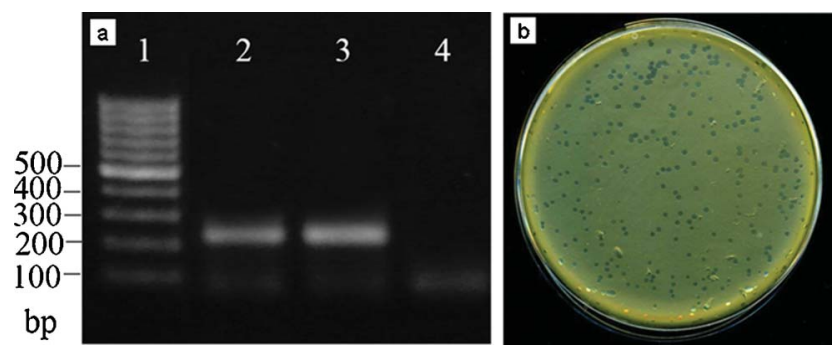

Fig. 5 (a) DNA fragments after amplification of characteristic DNA of moderate phages: (1) DNA-marker, (2) x411-f, (3) x415-f, (4) L. lactis 502. (b) Negative colonies formed after analysis of the lysogenic bacteria suspension after UV irradiation with $\mathrm{TiO}_{2}$. 
after analysis of the lysogenic bacteria suspensions after UV irradiation with $\mathrm{TiO}_{2}$. Thus, the method suggested here is effective for titania-assisted detection of DNA and lysogenic bacteria.

\section{Conclusions}

In particular, we studied the kinetic activity and the mechanism of bacteriophage deactivation and compared it with bacterial deactivation. We demonstrated that the novel titania-assisted photocatalytic method of bacteriophage detection has $100 \%$ efficiency during bacteriophage release from lysogenic bacteria. The kinetic activity of the deactivation of bacteriophages dramatically exceeds that of bacterial deactivation. We also showed that the time for detection of lysogenic bacteria is less than for bacterial deactivation. Thus, release of bacteriophages from bacteria is not accompanied by the inactivation of bacteriophages. The procedure of photocatalytic lysogenic bacteria detection includes the following steps: (a) obtaining of daily lysogenic bacteria cultures by the standard methods; ${ }^{16-18}$ (b) cultivation of lysogenic bacteria in a sterile physiological solution and addition of the nanodispersed titania photocatalyst to the resultant suspension; (c) UV-irradiation of the mixed suspension; (d) seeding of the irradiated culture by a standard two-layer method ${ }^{19}$ with the subsequent crops incubated for some days; (e) calculation of number of negative colonies and concentration of phages (PFU $\mathrm{ml}^{-1}$ ). The method suggested here of lysogenic bacteria detection is significantly cheaper and simpler in comparison to PCR considering that LTSUVI decreased the time of detection from $2 \mathrm{~h}$ to $2 \mathrm{~min}$.

\section{Acknowledgements}

This work was supported by the Humboldt Foundation, SFB840, NATO CLG 984267. D. V. S. acknowledges the support from NATO CLG 984063, FP7 project "Photocontrol" and from the Basic Research Foundation of Belarus.

\section{Notes and references}

1 M. R. Hoffman, S. T. Martin, W. Choi and D. W. Bahnemann, Environmental applications of semiconductor photocatalysis, Chem. Rev., 1995, 95, 69-96.

2 A. Fujishima, T. N. Rao and D. A. Truk, Titanium dioxide photocatalysis, J. Photochem. Photobiol., C, 2000, 1, 1-21.

3 D. G. Shchukin and D. V. Sviridov, Photocatalytic processes in spatiallyconfined micro and nanoreactors, J. Photochem. Photobiol., C, 2006, 7, $23-39$.

4 A. Markowska-Szczupaka, K. Ulfigb and A. W. Morawskie, The application of titanium dioxide for deactivation of bioparticulates: An overview, Catal. Today, 2011, 169, 249-257.
5 E. V. Skorb, E. A. Ustinovich, A. I. Kulak and D. V. Sviridov, Photocatalytic activity of $\mathrm{TiO}_{2}: \mathrm{In}_{2} \mathrm{O}_{3}$ nanocomposite films towards the degradation of arylmethane and azo dyes, J. Photochem. Photobiol., A, 2008, 193, 97-102.

6 F. Han, V. S. R. Kambala, M. Srinivasan, D. Rajarathnam and R. Naidu, Tailored titanium dioxide photocatalysts for the degradation of organic dyes in wastewater treatment: A review, Appl. Catal., A, 2009, 359, 25-40.

7 D. G. Shchukin, E. A. Ustinovich, A. I. Kulak and D. V. Sviridov, Heterogeneous photocatalysis in titania-containing liquid foam, Photochem. Photobiol. Sci., 2004, 3, 157-159.

8 M. N. Chong, B. Jin, C. W. K. Chow and C. Saint, Recent developments in photocatalytic water treatment technology: A review, Water Res., 2010, 44, 2997-3027.

9 T. Matsunaga, T. Tomoda, N. Nakajima and H. Wake, Photochemical sterilization of microbial cells by semiconductor powder, FEMS Microbiol. Lett., 1985, 29, 211-214.

10 V. Nadtochenko, N. Denisov, O. Sarjusiv, D. Gumy, C. Pulgarin and J. Kiwi, Laser kinetic spectroscopy of the interfacial charge transfer between membrane cell walls of E. coli and $\mathrm{TiO}_{2}, J$. Photochem. Photobiol., A, 2006, 181, 401-407.

$11 \mathrm{G}$. Rincon and C. Pulgarin, Effect of $\mathrm{pH}$, inorganic ions, organic matter and $\mathrm{H}_{2} \mathrm{O}_{2}$ on $E$. coli $\mathrm{K} 12$ photocatalytic inactivation by $\mathrm{TiO}_{2}$ Implications in solar water disinfection, Appl. Catal., B, 2004, 51, 283302.

12 K. Sunada, T. Watanabe and K. Hashimoto, Bactericidal Activity of Copper-Deposited $\mathrm{TiO}_{2}$ Thin Film under Weak UV Light Illumination, Environ. Sci. Technol., 2003, 37, 4785-4789.

13 E. V. Skorb, L. I. Antonouskaja, N. A. Belyasova, D. G. Shchukin and D. V. Sviridov, Antibacterial activity of thin-film photocatalysts based on metal-modified $\mathrm{TiO}_{2}$ and $\mathrm{TiO}_{2}: \mathrm{In}_{2} \mathrm{O}_{3}$ nanocomposite, Appl. Catal., $B, 2008,84,94-99$.

14 O. K. Dalrymplea, E. Stefanakosa, M. A. Trotzb and D. Y. Goswami, A review of the mechanisms and modeling of photocatalytic disinfection, Appl. Catal., B, 2010, 98, 27-38.

15 H. A. Foster, I. B. Ditta, S. Varghese and A. Steele, Photocatalytic disinfection using titanium dioxide: spectrum and mechanism of antimicrobial activity, Appl. Microbiol. Biotechnol., 2011, 90, 18471868.

16 M. Bellantone, H. D. Williams and L. L. Hench, Broad-spectrum bactericidal activity of $\mathrm{Ag}_{2} \mathrm{O}$-doped bioactive glass, Antimicrob. Agents Chemother., 2002, 16, 1940-1945.

17 A. Henglein, Physiochemical properties of small metal particles in solution: 'Microelectrode' reactions, chemisorption, composite metal particles, and the atom-to-metal transition, J. Phys. Chem., 1993, 97, 5457-5471.

18 E. V. Skorb, D. G. Shchukin and D. V. Sviridov, Hybrid silicazirconia films loaded with titania nanoparticles and titania-based nanocontainers: Novel materials for thin-film photocatalysts and photocontrollable coatings, In: Molecular and Nanoscale Systems for Energy Conversion, ed. S. Varfolomeev et al., Nova Science Publishers, New York, 2008, 75-87.

19 D. Lillehaug, An improved plaque assay for poor plaque-producing temperate lactococcal bacteriophages, J. Appl. Microbiol., 1997, 83, 85-90.

20 B. del Rio, A. G. Binetti, M. C. Martín, M. Fernandez, A. H. Magadan and M. A. Alvarez, Multiplex PCR for the detection and identification of dairy bacteriophages in milk, Food Microbiol., 2007, 24, 75-81.

$21 \mathrm{~A}$. R. Huggins and W. E. Sandine, Incidence and properties of temperate bacteriophages induced from lactic streptococci, Appl. Environ. Microbiol., 1977, 33, 184-191. 